\title{
Measuring Service Quality Effect on Consumer Purchase Intention in Retailing
}

\author{
Dr. Trilok Pratap Singh, \\ Assistant Professor, \\ Institute of Business Management, \\ GLA University, 17 Km. stone, NH\#2 Mathura-Delhi Road, \\ Chaumuhan, Mathura-281406 (U.P). India \\ Tel: +91-8474901787 \\ E-mail: trilok.pratap@gla.ac.in
}

\begin{abstract}
The objective of this research is to measure the impact of service quality on consumer purchase intention in the retail environment. Implicitly, natural and informative focus has an effect on the customer's buying intentions. For qualitative analysis, data were collected from 477 customer surveys in large retail stores. The findings of the study indicate that quality of service have a positive effect on the purchase intention of the consumer. The results also showed that consumers do not intervene with pricing in large retail stores, as consumers feel that fair pricing are charged by retailers. Most consumers depend on the reputation and efficiency of the service quality.
\end{abstract}

Keywords: Service quality; Purchase intention; Retail environment; Targeting; Segmentation; Consistency.

\section{Introduction}

Service quality has become a significant research subject in the last decade. The competitive retail landscape now recognizes the high quality of service delivery as a critical retail strategy. Retailers should use the warehouse to enhance their retail strategy. The retail sector, therefore, needs inspection and evaluation. High-quality service delivery has been seen as a critical retail strategy in today's dynamic retail climate. In this case, companies rely more on consumer loyalty and customer retention for the new marketing model. Value is an ambiguous term to define as an observable, intangible, and even subjective time that people can perceive differently. Consumers can focus on the quality of a service or on the competition with market rivals. Producers may calculate the level of conformity or the degree to which the service was correctly established 
International Journal of Modern Agriculture, Volume 9, No.3, 2020

ISSN: 2305-7246

(Dedeke, 2016). Quality practitioners define quality in many ways, but in the most common interpretation, describing the condition as: 'meeting the needs of the client or the consumer.' After manufacturing the product and before delivering the services companies check the product and services to the required standard and then delivered to the market and that rules should be established according to the customer expectations because customer gives the tag of the quality product only when that product or services satisfies the level of expectation (Haaker et al., 2006). Quality can also be characterized as monitoring of product and service output to the expected level. (Meesala and Paul, 2018) points out that performance monitoring of design, development, or engineering processes can be carried out in the same way as time and cost management.

Success can be seen from a variety of perspectives. Let's take a different perspective. Innate quality is a motivating concept of integrity. All of them believe that the price is absolute and recognizable (Filieri et al., 2018). According to (Dai and Lee, 2018), the definition of consistency as quality means that it is "before definition ... as a concrete fact independent of and before theoretical abstraction." The degree of product-based insight is derived from the appropriate content. The differences in material quantity or attribute are qualitative (Garvin, 1984). This methodology is more formal than the physical features of the product. Performance is the degree to which the product/service meets or exceeds the expectations of the consumer (Panigrahi et al., 2018). Performance is at the heart of production and service. Consistency is defined as the key (Crosby, 1979). The efficiency of compliance ensures that the product meets the design requirements. This shows that precision is an integral part of engineering and technology. The prices are given at a fair price. This statement supports the claim that the costeffectiveness of purchasers must be weighed down.

\section{Literature Review}

Value is the basic subjective concept of each person. Quality may have two technical meanings: first, the quality of the product or service, which depends on the ability of the product or service to meet actual or implicit requirements, and second, the poor quality of the product or service (Brady et al., 2001). Price may have two technological implications. Quality may be term as "The totality of features and characteristics of a product or service that bear upon its ability to satisfy or implied needs." Quality is the presence or absence of various characteristics. Quality is 
not cheap, but it is less expensive than scrap. So the management must emphasize quality and consider it as a cultural requirement in any enterprise. (Hamari et al., 2017).

Performance is one of the strategic objectives of shifting from development literature to service. The costs, time, flexibility, and quality suggested by Hayes and Wheelwright (1984) are competing priorities for the US and foreign producers. The description includes the different metrics from which the quality tests are carried out. Various definitions have led to the creation of quality concepts, 'quality is desirable,' 'quality is of interest,' 'quality meets and exceeds consumer standards' (Reeeves and Bednar, 1994). The first two principles do not guide quality control, and the third one is used more extensively in quality management. The latter description was considered appropriate in the setting of the service (Kuo et al., 2009).

Performance is descriptive, not only about the nature of the product, but also about the service environment, but both opinions differ. Manufacturing performance is an objective calculation and a subjective evaluation in the service sector. Heterogenic, personal output, and goods (services) are inseparable from development and operation (Soltani et al., 2016).

The quality of care consists of three components: medical, technical goodness, determined by its efficacy, interpersonal virtue, assessed in part by its contribution to clinical treatment, and facility goodness (Avedis, 1989). This definition of quality gives the component of quality care. For enhancing quality care, marketers have to care about technical dimension measures by the effectiveness of the technical dimension added by the interpersonal relationship (Su et al., 2016).

\section{Service quality as an Antecedent of Consumer purchase intention}

Frostig and Maslow (1970) put safety standards second only to psychological needs based on a 5-stage hierarchy of human needs via his theory of incentives Well-being is, as we know, one of the most critical factors in quality. Similarly, Vosen et al. (1992) found that bacteria and fat were among the most significant concerns among respondents in the consumer health purchase study. Garvin (1987) also offers a well-known product quality thinking model based on eight dimensions: efficiency, functionality, durability, compliance, longevity, serviceability, aesthetics, 
International Journal of Modern Agriculture, Volume 9, No.3, 2020

ISSN: 2305-7246

and perceived quality. However, we need to consider service level determinants. Reliability, Tangibility, Efficiency, Empathy, and Sensitivity, Zeithaml et al. (1990) decide on the quality of service. Some of the prominent factors described as:

\section{Quality: An Exploration through Literature}

According to Businessdictionary.com, "Accomplishment of a given task measured against preset standards of accuracy, completeness, cost, and speed." This definition clearly mentioned performance is the value delivery with predetermined standards. There are so many variables to measure performance some of them are cost, speed, completeness especially in projects, accuracy etc. Some other researchers explain performance as a primary function of product and service (Dedeke, 2016). "Performance is the primary operating characteristics of a product" (Garvin, 1987). While several scholars have tried to establish a consistent meaning of success, the debate in academic literature continues today, particularly about certain aspects of language, the degree of understanding, and the conceptual basis for assessment (Ford and Schellenberg, 1982). There are three different degrees of success in Venkatraman and Ramanujan (1986). So we differentiate between financial performance, market success, and organizational efficiency, and later we were called organizational effectiveness. Manufacturing firms have identified "efficiency" as the main component of a competitive quality strategy. This aspect refers to the primary operating assets of a business, those that are important to the Customer's use of the product (Rose and Nabil, 2002).

Tangibility features are the secondary characteristics of a product that complement its core functionality. The Customer's criterion for measuring the quantity and quality of the products. If some product has relatively more features, then it may be a quality product. That is the only reason companies want to enhance the number of uses for a particular product to take competitive advantages (Huang et al., 2014). To make a competitive advantage, companies either adopt cost leadership or product differentiation. In product differentiation companies promote their unique features which are not available in competitors' product. Features are those attributes of the product through which Customers understand precisely what the company offers. Marketers have to elaborate on every element of the product for enhancing the sale. Many firms give a detailed description of its product features since features project the benefits which 
International Journal of Modern Agriculture, Volume 9, No.3, 2020

ISSN: 2305-7246

customers get at the time of using or consuming that product. Zhang and Dran (2000) aim to evaluate the efficiency of customer satisfaction on the website. Their work shows that hygiene and motivation factors contribute to website frustration and can be used as web design features. Based on this study, we can say that customer satisfaction, and dissatisfaction lead by consumer purchase intention has featured as a strong determinant.

The reliability of the probability of failure-free outcomes can be described in several ways over time. This shows a degree of trust in the efficiency of the client over time. Product reliability depends on how well it meets the design requirements. Garvin (1987) notes, however, that while enforcement includes "intended use" of drugs, reliability is related to "free use."

Reliability in the marketing of services is the ability to deliver a branded service consistently and precisely (Susan and McDaniel, 1995). This clearly shows in-service safety, dependability, and accurately is the two prominent attribute, reliability of the customers means providing service matched to the customers' expectations with a high level of accuracy.

Conformance in quality means at what degree the product and service matches to their prerequisites demand. The degree to which the physical characteristics and performance of the product meet the design requirements (Garvin, 1987). Producers and guardians aim to meet quality standards because they can generally be described and measured. Specifications are developed to ensure that goods and services do not have defects that may interfere with their function. The use of exercise can, therefore, be operated as a standard, since the rule is sufficiently defined. Service quality requires aspects relevant to the service delivery process and discusses intangible elements such as ease of operation, protection, and added value of customer information.

Instead of product features, image-based costs, brand names, or advertisements are subjectively assessed (Garvin, 1987). Also, customers viewed the price as true to their experience. Perception is the stage in which a person gathers, arranges, and interprets stimuli in a meaningful image. Some studies combine perceived performance and service quality. Parasuraman et al. (1985) describe service quality as "a global opinion or attitude about service superiority." They also 
International Journal of Modern Agriculture, Volume 9, No.3, 2020

ISSN: 2305-7246

refer to the sense of service quality perceived as concepts and perceptions of perception: "perceived quality is seen as the degree and direction of the discrepancy between customer perception and perception."

From the various factors of service marketing assurance related to the employee's performance. In service marketing, employees are one of the most prominent dimensions that are the only reason people are one of the parts of the service marketing mix. Assurance is directly proportionate to the employees' competences through which an organization generates trust and confidence. Warranty (Susan and McDaniel, 1995) can be described as awareness and courtesy of employees and how to foster faith and trust in the performance of employees. Many of the researchers' emphasized on staff training to develop this type of competence. The greatest obstacle to training personnel is the level of subjectivity and, therefore, the predictability of the process. The objective, reliable service can be assumed to follow a well-defined route with excellent results. This type of service may be considered appropriate for script-based use, as both the Customer and the service staff would be aware of the purpose of the service and the intended route for the service (Galloway and Ho, 1996).

Responsiveness often relies on the efficiency of the service. The desire to serve customers and to provide timely service should be reflected. Customers do not want to wait in any kind of advertisement; they just choose the service providers that offer their services promptly. Heinonen and Strandvik (2007) are proposing a mobile response measurement system. Reaction refers to the ability of the consumer to respond. It is a crucial aspect of the marketing of services. Empathy ensures that the company gives personalized attention to its customers. Customers will welcome service providers tailored to their needs. When a service provider provides unique or individual customer service, it is a premium service.

Customer satisfaction is the most important way to measure the performance of the quality assurance system of a product. (Cothran and Kaeter, 1992) announced that Globe Machining had to follow the quality assurance criteria of the Customer's dissatisfaction. The success of his program was evident in the successful adaptation of these needs. Many companies encourage the desire to work and benefit from competitive advantages. Xerox (Caudron, 1991) officially 
embarked on a quality improvement program as its market share declined sharply due to Japanese competition. Xerox realized that customer loyalty increased by $40 \%$ and that complaints increased by $60 \%$. (Galagan, 1990) estimates that $20 \%$ of manufacturing revenues have been lost because the goods have been handled unsatisfactorily, or the wishes of the consumer have been violated. Customer satisfaction is the primary way in which companies can measure, but not the only way, the service process. All these variables are equally relevant to the implementation of the customer satisfaction model by using 'scale,' 'product features' and 'product reliability' for their accuracy.

Service Quality Dimensions

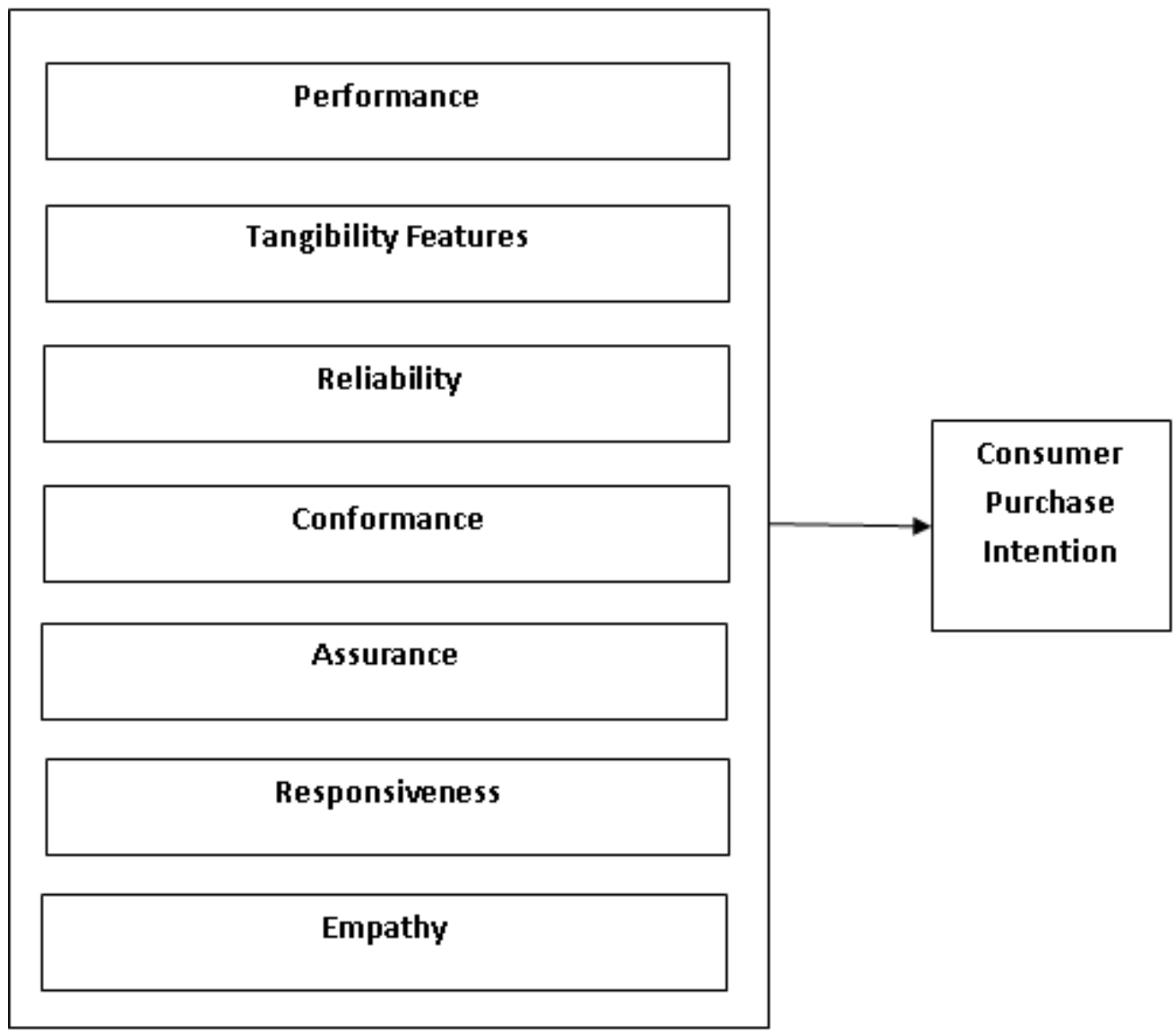

Conceptual Framework of the Study

\section{Research Methodology}

As mentioned earlier that this study measured the impact of service quality on consumer purchase intention in the retail environment. For this, seven service quality dimensions have 
been extracted from Lang and Mcmellon (2004). Items for these dimensions have also been removed from the same study. The consumer purchase intention scale has been obtained from Porral and Mangin (2017). This questionnaire comprised 48 questions, 4 demographics (gender, age, occupation, and qualification) and 44 opinion-based questions where respondents have to answers on 5 points Likert scale where one means strongly disagree, and five means strongly agree. Reliability and validity have been established shown in table 1. All the reliability measures are more significant than 0.7 creates the safety of the scale. Efficacy has been calculated through the average variance extracted (AVE). AVE values of all the variables are above the threshold value i.e., 0.5 .

Table 1: Reliability and Validity Measures

\begin{tabular}{clccc}
\hline Variable Number & Variables taken for the study & Cronbach alpha statistics & AVE & No. of Items \\
\hline 1 & Performance & 0.851 & 0.644 & 6 \\
2 & Tangibility Features & 0.802 & 0.582 & 5 \\
3 & Reliability & 0.858 & 0.613 & 5 \\
4 & Conformance & 0.785 & 0.687 & 4 \\
5 & Assurance & 0.881 & 0.711 & 7 \\
6 & Responsiveness & 0.914 & 0.572 & 7 \\
7 & Empathy & 0.732 & 0.543 & 6 \\
8 & Consumer Purchase Intention & 0.877 & 0.661 & 4 \\
\hline
\end{tabular}

Respondents of this survey are comprised of the consumers who visited various malls in Delhi, Gurgaon, Noida, Agra, and Banglore. Convenience sampling method has been used for data collection, and individual respondent was the sampling element. 477 responses have been taken during the period of November-December 2019.

Multiple regression analysis was used to measure the consumer's desire to purchase quality service dimensions. Composite performance of all service quality structures, considered to be independent variables, intended for acquisition as dependents. Before the study, data normality was defined as a prerequisite for multiple regressions.

\section{Data Analysis and Interpretation}

Data analysis has been done in two steps in first demographic analysis has been done through MS Excel and then multiple regression has been applied on Performance, Tangibility Features, 
International Journal of Modern Agriculture, Volume 9, No.3, 2020

ISSN: 2305-7246

Reliability, Conformance, Assurance, Responsiveness and Empathy as a independent variables and Consumer Purchase Intention as a dependent variable. Data have been taken as a composite score for all the eight variables and data analysis has been done on SPSS 24 software.

Table 2 represents demographic profile of the respondents. This table clarify that $74.21 \%$ of the respondents were male, $38 \%$ of the sample were from age group of 25 to 40 years.

Table 2: Demographic Profile

\begin{tabular}{|c|c|c|c|}
\hline Demographic & $\mathbf{N}$ & $\%$ & $\begin{array}{c}\text { Cumulative } \\
\%\end{array}$ \\
\hline \multicolumn{4}{|l|}{ Gender } \\
\hline Male & 354 & 74.21 & 74.21 \\
\hline Female & 123 & 25.79 & 100.00 \\
\hline \multicolumn{4}{|l|}{ Age } \\
\hline Less than 25 & 164 & 34.38 & 34.38 \\
\hline $25-40$ & 182 & 38.16 & 72.54 \\
\hline $40-60$ & 84 & 17.61 & 90.15 \\
\hline Greater than 60 & 47 & 9.85 & 100.00 \\
\hline \multicolumn{4}{|l|}{ Occupation } \\
\hline Employed & 237 & 49.69 & 49.69 \\
\hline Self-employed & 139 & 29.14 & 78.83 \\
\hline Unemployed & 101 & 21.17 & 100.00 \\
\hline \multicolumn{4}{|l|}{ Qualification } \\
\hline Intermediate & 44 & 9.22 & 9.22 \\
\hline UG & 236 & 49.48 & 58.70 \\
\hline PG & 197 & 41.30 & 100.00 \\
\hline
\end{tabular}

Multiple regression results have been shown in table 3 to 5.Table 3 represents the regression statistics for Consumer purchase intention and Quality. $\mathrm{R}^{2}$ value is $67.1 \%$ which means that $67.1 \%$ variance have been explained by independent variables for dependent variable or in simple words that predictability power is $67 \%$ which is good in case of management research. Standard error is 0.271 reflects good regression model. It shows the small difference or dispersion along the regression line. 
International Journal of Modern Agriculture, Volume 9, No.3, 2020

ISSN: 2305-7246

Table 3: Regression Statistics for Consumer purchase intention and Service Quality in Retailing

\begin{tabular}{|l|r|r|r|r|}
\hline Model & $\mathrm{R}$ & $\mathrm{R}$ Square & $\begin{array}{c}\text { Adjusted R } \\
\text { Square }\end{array}$ & $\begin{array}{c}\text { Std. Error of the } \\
\text { Estimate }\end{array}$ \\
\hline 1 & $.819^{\mathrm{a}}$ & .671 & .666 & .271 \\
\hline
\end{tabular}

a. Predictors: (Constant), Empathy, Assurance, Performance,

Reliability, Responsiveness, Conformance, Tangibility Features

Table 4 is an all-important regression model. The p-value here is p-000, which shows the overall significance of the reduction between the dimensions of the quality of the service and the intention to purchase the product.

Table 4: ANOVA table for Consumer purchase intention and Service Quality in Retailing

\begin{tabular}{|c|c|c|c|c|c|c|}
\hline \multicolumn{7}{|c|}{ ANOVA $^{a}$} \\
\hline & & Sum of Squares & df & Mean Square & $\mathrm{F}$ & Sig. \\
\hline \multirow{3}{*}{1} & Regression & 69.998 & 7 & 10.000 & 136.496 & $.000^{\mathrm{b}}$ \\
\hline & Residual & 34.359 & 469 & .073 & & \\
\hline & Total & 104.356 & 476 & & & \\
\hline
\end{tabular}

a. Dependent Variable: Consumer Purchase Intention

b. Predictors: (Constant), Empathy, Assurance, Performance, Reliability, Responsiveness,

Conformance, Tangibility Features

Table 5 shows the $\mathrm{t}-$ value and $\mathrm{p}$-value of all independent regression variables when examining service dimensional output and customer purchase intent. All p-values are calculated below.05 by the input and effect of each independent variable on the purchase of the consumer. Multicollinearity has also been examined. No case of multicollinearity for all VIF values below 5 has been developed.

Table 5: $t-$ value and $p-$ value for the regression result between Consumer purchase intention and Quality in Metro city

\begin{tabular}{|c|c|c|c|c|c|c|c|}
\hline \multicolumn{8}{|c|}{ Coefficients $^{a}$} \\
\hline Model & \multicolumn{2}{|c|}{$\begin{array}{c}\text { Unstandardized } \\
\text { Coefficients }\end{array}$} & $\begin{array}{c}\text { Standardized } \\
\text { Coefficients }\end{array}$ & \multirow[t]{2}{*}{$t$} & \multirow[t]{2}{*}{ Sig. } & \multicolumn{2}{|c|}{$\begin{array}{c}\text { Collinearity } \\
\text { Statistics }\end{array}$} \\
\hline & $\mathrm{B}$ & Std. Error & Beta & & & Tolerance & VIF \\
\hline 1 (Constant) & -.151 & .126 & & -1.197 & .232 & & \\
\hline
\end{tabular}


International Journal of Modern Agriculture, Volume 9, No.3, 2020

ISSN: 2305-7246

\begin{tabular}{|l|l|l|r|r|r|r|r|}
\hline Performance & .157 & .016 & .269 & 10.028 & .000 & .978 & 1.023 \\
Tangibility Features & .147 & .015 & .259 & 9.513 & .000 & .944 & 1.059 \\
Reliability & .170 & .015 & .294 & 10.994 & .000 & .979 & 1.022 \\
Conformance & .155 & .015 & .285 & 10.586 & .000 & .972 & 1.029 \\
Assurance & .156 & .016 & .266 & 9.806 & .000 & .955 & 1.048 \\
Responsiveness & .124 & .014 & .232 & 8.606 & .000 & .969 & 1.032 \\
Empathy & .144 & .015 & .268 & 9.885 & .000 & .952 & 1.050 \\
\hline
\end{tabular}

a. Dependent Variable: Consumer Purchase Intention

\section{Discussion and Implications of the Study}

This research discusses a new issue: the efficiency of facilities being continually analyzed by researchers, administrators, and media commentators. This research aims to quantify and demonstrate the impact of service quality on consumer purchases by providing predictive models between service quality variables and customers.

CPI $=-0.151+0.157$ Performance +0.147 Tangibility features +0.17 Reliability +0.155 Conformance + 0.156 Assurance + 0.124 Responsiveness + 0.144 Empathy

The conceptual price model is shown in Figure 1. This conceptual model defines the variables that inspire the purchase of customers. Peoples become more mature in terms of consumers when they are spending money now more concern towards quality to get value for money. Consumers are always a concern for quality. Hammer (2001), an integrated community of similar activities that together generate value for customers, also describes the quality of service. There are various variables of defining quality dimensions. For taking marketing competitive advantage in understanding consumer purchase intention concerning quality, marketers have to focus on the variables such as performance, tangibility features, reliability, conformance, assurance, responsiveness, and empathy. Regression tests showed a significant linear correlation between the purchase intention and the quality of the retail service. Better product quality would undoubtedly lead to a higher degree of positive customer purchase intention. Marketers need to set high-quality deals for ambitious customer purchase intentions. 
International Journal of Modern Agriculture, Volume 9, No.3, 2020

ISSN: 2305-7246

\section{Limitation of the study}

\section{Reference}

1. Brady, M. K., \& Robertson, C. J. (2001). Searching for a consensus on the antecedent role of service quality and satisfaction: an exploratory cross-national study. Journal of Business research, 51(1), 53-60.

2. Caudron, S. (1991). How Xerox Won the Baldrige. Personnel Journal, 70(4), 98-102.

3. Coates, H. (2005). The value of student engagement for higher education quality assurance. Quality in higher education, 11(1), 25-36.

4. Cothran, T. and Kaeter, M. (1992). Pioneering Quality Training, Training, special report, April 1992, 13-18.

5. Dai, W., \& Lee, J. H. (2018). Effects of website characteristics and delivery service quality on repurchase intention. The International Journal of Industrial Distribution \& Business, 9(5), 17-24.

6. Dedeke, A. N. (2016). Travel web-site design: Information task-fit, service quality and purchase intention. Tourism Management, 54, 541-554.

7. Dedeke, A. N. (2016). Travel web-site design: Information task-fit, service quality and purchase intention. Tourism Management, 54, 541-554.

8. Donabedian, A. (1989). Institutional and professional responsibilities in quality assurance. International Journal for Quality in Health Care, 1(1), 3-11.

9. Filieri, R., McLeay, F., Tsui, B., \& Lin, Z. (2018). Consumer perceptions of information helpfulness and determinants of purchase intention in online consumer reviews of services. Information \& Management, 55(8), 956-970.

10. Ford, J.D. , \& Schellenberg, D.A. (1982). Conceptual issues of linkage in the assessment of organizational performance. Academy of Management Review . 7, 49-58.

11. Frostig, M., \& Maslow, P. (1970). Movement education: Theory and practice. Follett Educational Corp..

12. Galagan, P.A. (1990). A CEO's View of Training. Training \& Development, 44(5), 4050.

13. Galloway, L. and Ho, S. (1996). A model of service quality for training. Training for Quality, 4(1), 20 - 26.

14. Garvin, D.A (1984). What does product quality really mean? Sloan Management Review, 25-43.

15. Garvin, D.A. (1987). Competing on the Eight Dimensions of Quality. Harvard Business Review, 65(6), 101-109.

16. Haaker, T., Faber, E., \& Bouwman, H. (2006). Balancing customer and network value in business models for mobile services. International Journal of Mobile Communications, 4(6), 645-661. 
17. Hamari, J., Hanner, N., \& Koivisto, J. (2017). Service quality explains why people use freemium services but not if they go premium: An empirical study in free-to-play games. International Journal of Information Management, 37(1), 1449-1459.

18. Hammer, M. (2001). The Agenda: What every business must do to dominate the decade, 51-60, Crown Business Publishing Gr.

19. Hayes, R.H. and Wheelwright, S.C. (1984). Restoring Our Competitive Edge. New York: John Wiley \& Sons.

20. Heinonen, Kristina \& Strandvik, Tore (2007). Consumer responsiveness to mobile marketing. International journal of mobile marketing, 5(6), 603-617.

21. Huang, C. C., Yen, S. W., Liu, C. Y., \& Huang, P. C. (2014). The relationship among corporate social responsibility, service quality, corporate image and purchase intention. International Journal of Organizational Innovation (Online), 6(3), 68.

22. Huang, C. C., Yen, S. W., Liu, C. Y., \& Huang, P. C. (2014). The relationship among corporate social responsibility, service quality, corporate image and purchase intention. International Journal of Organizational Innovation (Online), 6(3), 68.

23. Kuo, Y. F., Wu, C. M., \& Deng, W. J. (2009). The relationships among service quality, perceived value, customer satisfaction, and post-purchase intention in mobile valueadded services. Computers in human behavior, 25(4), 887-896.

24. Lang, M. and McMellon, C. (2004). Exploring the determinants of retail service quality on the Internet. Journal of Services Marketing, 18 (1), 78-90.

25. Meesala, A., \& Paul, J. (2018). Service quality, consumer satisfaction and loyalty in hospitals: Thinking for the future. Journal of Retailing and Consumer Services, 40, 261269.

26. Panigrahi, S. K., Azizan, N. A., \& Khan, M. W. A. (2018). Investigating the empirical relationship between service quality, trust, satisfaction, and intention of customers purchasing life insurance products. Indian Journal of Marketing, 48(1), 28-46.

27. Parasuraman, A., Zeithaml, V. and Berry, L. (1985). A conceptual model of service quality and its implications for future research. Journal of Marketing, 49(Fall), 41-50.

28. Porral, C. C. and Mangin, J. P. (2017). Store brands' purchase intention: Examining the role of perceived quality. European Research on Management and Business Economics, 3 (2), 90-95.

29. Reeves, C. A., \& Bednar, D. A. (1994). Defining quality: alternatives and implications. Academy of management Review, 19(3), 419-445.

30. Rose Sebastianelli and Nabil Tamimi (2002). How product quality dimensions relate to defining quality? International Journal of Quality \& Reliability Management, 19(4), 442453.

31. Soltani, M., Esfidani, M. R., Jandaghi, G., \& Soltaninejad, N. (2016). The effect of service quality on private brand image and purchase intention in the chain stores of ETKA. World Scientific News, 47(2), 202-216. 
32. Su, L., Swanson, S. R., \& Chen, X. (2016). The effects of perceived service quality on repurchase intentions and subjective well-being of Chinese tourists: The mediating role of relationship quality. Tourism Management, 52, 82-95.

33. Susan E. Pariseau and J.R. McDaniel (1995). Assessing service quality in schools of business. International Journal of Quality\& Reliability Management, 14(3), 204-218.

34. Venkatraman, N., \& Ramanujam, V. (1986). Measurement of business performance in strategy research: A comparison of approaches. Academy of Management Review, 11, 801--814.

35. Vosen, T.R., Mikel, W.B., Mulvaney, D.R. and Jones, W.R. (1992), “A survey of consumerattitudes toward beef safety", Dairy, Food and Environmental Sanitation, Vol. 12 No. 10, pp. 621-624.

36. Zeithaml, V.A., Parasuraman, A., and Berry, L.L. (1990). Delivering quality service balancing customer perceptions and expectations. New York: The Free Press.

37. Zhang, P., and von Dran, G. M. (2000). Satisfactor and dissatisfactorers: A two-factor model for website design and evaluation. Journal of the American Society for Information Science, 51(4), 1253-1268. 